㐘池 利邦・山下一也 山本 義憲・池原 勝広

頸静脈孔撮影の必要性は, 頸静脈孔付近に, 腫瘍があ り，それが就静脈孔付近の骨を侵す時，その程度の早期 邶断がのぞまれる場合，頸静脈孔の大きさそのものより， 小窩の描写，特に入日のうすい骨壁を観察ずることが重 要となる。一般的にこの付近に腫瘍ができると，めまい, 耳鳴り，難聴，耳からの出血等の症状が現われるといわ れております。

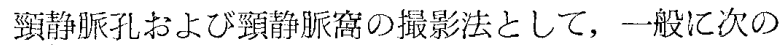
6っの方法があります。

1. Eraso の方法, 2. Choussi の方法, 3. Stenver の 方法, 4. Porcher の方法, 5. Terrahe の方法, 6 . Waters の変法で開口してする方法.

次上の撮影法走比較した結果，次の表のようになる。

\begin{tabular}{|c|c|c|c|c|}
\hline & $\begin{array}{l}\text { 孔ずす } \\
\text { ひずみ }\end{array}$ & 浻の描写 & $\begin{array}{l}\text { 骨との } \\
\text { 重なり }\end{array}$ & $\begin{array}{l}\text { 撮影のテ } \\
\text { タニック }\end{array}$ \\
\hline Eraso の方法 & 少ない & 明 瞭 & ない & 易しい \\
\hline Chaussie $\sigma$ 尿法 & ない & 不明瞭 & ある & 難しい \\
\hline Stenvew の方法 & 強い & 不明瞭 & ある & 難しひ \\
\hline Porcher の方法 & ない & 明 瞭 & 少しある & やや難しい \\
\hline Terrahe の方法 & ない & 非常に明瞭 & ない & やや難しい \\
\hline Water の方法 & 少ない & 不明瞭 & ある & やや難しい \\
\hline
\end{tabular}

私達は以上の撮影法を検討した結果，撮影のテクニッ クが簡単でしかも他の骨とのかさなりがなく，頸静脈孔 小窝の変形が少ないということで, 特に Era so, Porcher の法を検討した結果次のようになった。

左在対称飞頸静脈孔を見る場合は，体位は，背臥位で， 頭頂部をフィルム面につけて，ベースラインがX線の入 射方向に刘して $60^{\circ}$ から $75^{\circ}$ の範囲にとり, 中心線は下 顎より，頭頂方向で正中線と両外耳孔下縁を結ぶ線と交 わる点を入射点としてねらう。乙の点はほぼオトガイ隆 起より $2 \mathrm{~cm}$ 位下方の点になる。

次に頸静脈䆚を見る場合は，今のと同じ体位で，ただ 中心線は正中線と両外耳孔下緣を結ぶ線との交点を入射 点乞して固定しておき, 非検側に正中面を $10^{\circ} \sim 15^{\circ}$ 傾 斜して撮影, $10^{\circ} \sim 15^{\circ}$ の傾斜であれば中心線は, 下顎角, 下 $2 \mathrm{~cm}$ 位の点になる。

単純撮影で不明療であれば，全く同じ体位で小角度断 層撮影を行なえばよい.さい断面の深さは検查側の外耳 道, 上緣, 中下縁の3 枚を断層撮影すれば允分である.

以上，頸静脈孔腫瘍のレ線診断に有效な撮影法を検討 しその結果を報告しました。

\section{3. 茎状突起撮影の試み}

阪大病院放射線科
雄川 恭行・山上一也・宇位美達也

片山 博文・段床 嘉晴 $\cdot$ 伊藤 慎也

唩崎 重昭

側頭骨の茥状突起は，一般に外耳周过，後頭部加ら頸 部に至る部位任痛みを訴える時, 茥状突起の過長, 変形 等が起因している場合が多く，展さ，形状および茎状突 起と咽頭，舌筲等との関連をみるためX線の二方向撮影 が必要となる.乙の突起は錐体下面後外側端に位置し， 外耳口直下成人では約 $1 \mathrm{~cm}$ のとろにその起点走求め るととが出来る．突起の長さは通常 $1 \sim 5 \mathrm{~cm}$ で直徍は 1〜4mm. 耳垂線に対し約30度前方へ，また体軸方向に 約 $15^{\circ}$ 傾斜している．実際の撮影汇当っては上，下顎骨， 煩骨, 頸椎, 舌骨, 後頭蓋顆, 後頭顆等が障害になり易 く, 解剖学的位置関係は重要である.

[実験的検討]

(1) 頭蓋矢状面老莗直， $5^{\circ} ， 10^{\circ} ， 15^{\circ}$ と変化させ何れ の場合にも中心X線を垂值に茥状突起を狙った，この結 果，非検查側に頭を $5^{\circ} \sim 10^{\circ}$ 傾斜させたものが，よく突 起を現出せしめる。

(2) 頭蓋矢状面を非検査側に 5〜 $7^{\circ}$ 傾斜させたままで X線管を頭側に $20^{\circ}, 15^{\circ}, 10^{\circ}, 5^{\circ}, 0^{\circ}$ ，また足側にも同样 に傾斜させる丰験の結果，頭側に $5^{\circ} \sim 15^{\circ}$ 傾斜させたも のが上顎部および後頭部の洎害陰影の影響が最少である. これはW.A. Fuchs 氏の方法とほぼ一致する。

(3)開口時と閉口時では開口時の方が有利である.

(4)，側方向撮影の実験.耳垂線と平行に，しかもX線 管入射方向を足側加ら頭側に $0^{\circ}, 5^{\circ}, 10^{\circ}, 15^{\circ} \cdots \cdots$ と変化 させると次第に茎状乫起の根部まで現出してくる.しか し突起への斜入の度合も，頭側に $20^{\circ}$ 向けたときは中心 X線と突起のなす角は $50^{\circ}$ ，足側から $35^{\circ}$ 向けたときは $35^{\circ}$ 位乙急角度の斜入となる。したがって足側から頭側 へ $20^{\circ}$ 前後の傾斜が最良ではないか.

(5)なお，実験から耳垂線に平行に茎状突起に中心線 をむって行くのが，下顎骨からの分離に最適である。

(6) 閉口のまま頸椎と下顎とのなす角を最大にして撮 影するととが朋要である.

(7) この撮影では茥状突起は下顎軟部に現出し, 舌骨, 咽頭等との関連をさぐる目的にも合致している.ただ斜 入の度合が Fuchs 氏のむのより大きく，念頭に入れら れるべきである。

(8) 細い荠状突起でむ軟部組織の中でよいコントラス トを示し得る。

\section{4. 大腿骨頚部前捻角の計測について} 関西医科大学放射線科 


\section{小林 昭智}

○羽柴広・西井徹・山本武 山哲男 $\cdot$ 中川 忠嗣·西村 茂樹

\section{[目的]}

大腿骨頸部前捻角の計測方法は，きわめて不正確であ る。また，トモグラフィーを使用する場合生殖線量が問 題となる，演者等はサーカストモグラフィ一老使用し生 殖腺線量の可及的濊少及び計測精度の向上をはかった。

\section{[方法]}

仰臥位大腿部垂直位にて大腿骨内外顆おょび上前腸骨 棘を左右上方より固定し，下腿骨を最大内施位にて $150^{\circ}$, $60^{\circ}, 90^{\circ}$ と屈曲させ， $90^{\circ}$ で下腿骨下部をそのままの最 大内施位にて固定する．この三点に扔ける腓骨外顆の軌 跡を前記固定装置と一体構造の基線指示装置の三点汇置 換すると，乙の平面汇垂直な棒は，膝関節軸俉平行であ るから，乙の棒を断層の深さの如何にかかわらず，フィ ルム上に投影させるため, 垂直棒より 2 本の平行な七ュ ーズを含むアルミ板を㲘垂させ，トモグラムの 2 点のス ポットを結ぶ直線を基線とし，大腿骨頸部軸との角度を 直接計測した。骨無し MIX-D ファントムにて, 卵巣の 位置を小骨盤内でしかも左右腸骨陵分界線上の横径端, 恥骨結合によって形成される平面のA点, $\mathrm{B}$ 点とし, 睪 丸の位置はC点とし，シーメンスドージメーターにて可 及的诚少のために，プロテクター，フィルター, 振角変 化，同時多層等について，フィルム上の大腿骨頸部の部 分で同一濃度にする条件にて，実験を行なった。

[結論】

位置付時の誤差原因は，大腿費垂直不正による。一般 式は矢状方向においては， $\alpha^{\prime}=\left(1 \pm \frac{\sin a}{2 \sin \alpha}\right) \cdot \alpha$, 前額左 右方向においては， $\alpha^{\prime}=\left(1 \pm \frac{\tan a}{2 \cdot \cos \alpha}\right) \cdot \alpha$ (ただし， $a$ は 大腿骨体軸の傾斜角， $\alpha$ は前捻角の真值， $\alpha^{\prime}$ は大腿骨体 軸が $a^{\circ}$ 傾斜したときの前捻角とする）であり，誤差は 少なく, 誤差の大半は基線の不正によるものと推定でき る. 演者等の方法は, 骨標本によるトモグラムで, 関節 軸に平行な 2 点の基線スポットを忠実示し，良好な結 果を得た。

一方, 生殖腺線量は，(1)サーカストモグラフィーによ り, 振角 $30^{\circ}$ の場合, 円弧式卜モグラフィーに比して, 全早共に $1 / 2$ となる. (2) $\mathrm{Pb} 2 \mathrm{~mm}$ のプロテクターにより 合우共汇, 1/10 1/15 となる. (3) $\mathrm{Al} 1 \sim 2 \mathrm{~mm}$ フィルター により約20\%の減少となる，(4)多層カセッテにより，約 1/2亿減少できる.

総合して，サーカストモグラフィーを用いて，円弧式
に比して，約 $1 / 50$ の減少が得られた，以上，報告する. 質問

乳幼㫛の場合の固定の如何. （関西＼cjkstart前田）

\section{答}

成人にあっては，大腿骨頸部骨折等のみであり，前捻 角測定の対象は，ほとんど，乳幼児の股関節脱曰であり ます。測定時の固定は, マジックテープを随所任使用し， 特に上前腸骨棘抒よび大腿骨内外顆の固定を十分に行な うような，固定装置および基線指示装置（スライド参照） を使用しました。下腿骨と大腿骨とのなす角度は，最大

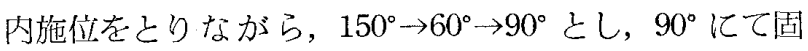
定します、乙机によって，確実に前捻角の棓測ができま す.

\section{5. 小児 X線検查法に関する種々の工夫}

大阪市立小児保健センター ○田中 袥輔・町田 同・井上日出男

胸部のX線䛦断では立位撮影を診断する者から要求さ れる，臥位では立位に比べ心臓の形は大きく広がり，肺 野は狭くなる，また，特に心藏の検査では立位でなけれ ば本当の形が分らない，暴れる子供は脚の屈伸運動に上 り，大地を強く䠞りその反動で暴れているととを知った ので，体を宙に吊り足を浮かせ快たと元手足を動かして も反動がないため, 案外, 胴体は動摇しない。このこと に注目してわれわれは市販されているウーリーナイロン 製の小供用海水着を子供に着用させ，肩の部分に紐を取 つけて，乙れでリーダー撮影台に吊り下げ撮影を行なっ た．との方法によればナイロンの弾力性と伸縮性により， 頭や胸を肩の部分の紐によって周りから適当に絞めつけ 固定されるので, まだ頸の坐っていない子供や生後間も ない未熟児でも立位で撮影できる，乙の方法は胸部，腹

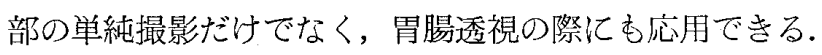
子供の撮影では呼四停止も行なえず，心藏の動きも激し いので，できる限りX線曝射時問を短縮するため操作盤 に 400mA のタップを新設し, $400 \mathrm{~mA}, 3 / 120 \mathrm{sec} ., 60$ $70 \mathrm{kVp}$ で胸部撮影を行なっている.

子供を葠た姿勢で撮影するとき，通常 Magic cast を 使用して，足と肩とで固定するが，乙の際，同時に 2 個 の Magic Cast を使用するためには市販のガスコンセン ト「カチット」(大阪ガス製) を使用すれば， 1 台の吸引 ボンプで 2 個以上の Magic Cast が同時に簡単に固定で きる。

われわれは子供の頭部を固定する方法として book end 式の固定具を考えた． 厚さ $3 \mathrm{~cm}$ の板をL字型に釘 づけし，本を立てる要領で頭を強く挾む．頭の悀みをな 